\title{
Antimicrobial Resistance of Enterococcus sp. Isolated from Sheep and Goat Cheeses
}

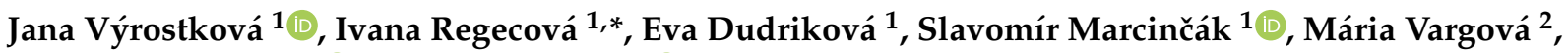 \\ Mariana Kováčová ${ }^{1}$ and Jana Mal'ová ${ }^{1}$ (D) \\ 1 Department of Food Hygiene Technology and Safety, University of Veterinary Medicine and \\ Pharmacy in Košice, Komenského 73, 04181 Košice, Slovakia; jana.vyrostkova@uvlf.sk (J.V.); \\ eva.dudrikova@uvlf.sk (E.D.); slavomir.marcincak@uvlf.sk (S.M.); mariana.kovacova@student.uvlf.sk (M.K.); \\ jana.malova@uvlf.sk (J.M.) \\ 2 Department of Public Veterinary Medicine and Animal Welfare, University of Veterinary Medicine and \\ Pharmacy in Košice, Komenského 73, 04181 Košice, Slovakia; maria.vargova@uvlf.sk \\ * Correspondence: ivana.regecova@uvlf.sk; Tel.: +421-907-185-658
}

\section{check for} updates

Citation: Výrostková, J.; Regecová, I.; Dudriková, E.; Marcinčák, S.;

Vargová, M.; Kováčová, M.; Mal’ová, J. Antimicrobial Resistance of Enterococcus sp. Isolated from Sheep and Goat Cheeses. Foods 2021, 10, 1844. https://doi.org/10.3390/ foods10081844

Academic Editors: Arun K. Bhunia, Andrea Serraino, Alessandra De Cesare and Federica Giacometti

Received: 23 June 2021

Accepted: 2 August 2021

Published: 10 August 2021

Publisher's Note: MDPI stays neutral with regard to jurisdictional claims in published maps and institutional affiliations.

Copyright: (c) 2021 by the authors. Licensee MDPI, Basel, Switzerland. This article is an open access article distributed under the terms and conditions of the Creative Commons Attribution (CC BY) license (https:// creativecommons.org/licenses/by/ $4.0 /)$.
Abstract: This study aimed to calculate the proportion of antibiotic resistance profiles of Enterococcus faecium, E. faecalis, and E. durans isolated from traditional sheep and goat cheeses obtained from a selected border area of Slovakia with Hungary (region Slanské vrchy). A total of 110 Enterococcus sp. were isolated from cheese samples, of which 52 strains (E. faecium (12), E. faecalis (28), E. durans (12)) were represented. After isolation and identification by polymerase chain reaction and matrix-assisted laser desorption/ionization-time-of-flight mass spectrometry, the enterococci (E. faecium, E. faecalis, and $E$. durans) were submitted to susceptibility tests against nine antimicrobial agents. In general, strains of E. faecalis were more resistant than E. durans and E. faecium. A high percentage of resistance was noted in E. faecalis to rifampicin (100\%), vancomycin $(85.7 \%)$, teicoplanin $(71.4 \%)$, erythromycin $(71.4 \%)$, minocycline $(57.1 \%)$, nitrofurantoin $(57.1 \%)$, ciprofloxacin $(14.3 \%)$, and levofloxacin $(14.3 \%)$. E. durans showed resistance to rifampicin (100\%), teicoplanin (100\%), vancomycin $(66.7 \%)$, erythromycin $(66.7 \%)$, nitrofurantoin $(66.7 \%)$, and minocycline (33.3\%), and E. faecium showed resistance to vancomycin, teicoplanin, and erythromycin (100\%). Multidrug-resistant strains were confirmed in $80 \%$ of the 52 strains in this study. Continuous identification of Enterococcus sp. and monitoring of their incidence and emerging antibiotic resistance is important in order to prevent a potential risk to public health caused by the contamination of milk and other dairy products, such as cheeses, made on farm level.

Keywords: antimicrobial resistance; cheese; Enterococcus sp.; MALDI-TOF; PCR

\section{Introduction}

Enterococci are Gram-positive bacteria belonging to the lactic acid bacteria (LAB) group. They occur mainly in the human intestine. They are commensal microorganisms, although over the last 20 years, due to the acquisition of antimicrobial resistance, they have become important hospital-acquired pathogens [1]. Nevertheless, they still have an important role in the production of fermented dairy products, such as cheeses, in prolonging their shelf life and improving their organoleptic properties [2,3].

However, the occurrence of enterococci in food is also an indicator of poor manufacturing practice and product contamination, as they are commonly present in raw milk, stressing the importance of focusing on both the raw materials used in cheese production and the products they encounter during production [4-6].

In addition to their function as indicators of poor manufacturing practice, enterococci have a technological function in the production of fermented products. However, they may exhibit different levels of antibiotic resistance, which is one of the main concerns of these food isolates [7-9]. Due to this ability, enterococci exhibit a wide repertoire of antibiotic 
resistance mechanisms. Enterococci can become the dominant flora in the gastrointestinal tract under antibiotic pressure, predisposing a severely ill and immunocompromised patient to invasive infections $[10,11]$.

Therefore, they have become recognized as important nosocomial pathogens due to their natural intrinsic resistance to several antimicrobials, as well as their ability to rapidly acquire virulence and determinants of multidrug resistance $[12,13]$.

Antimicrobial resistance is one of the critical public health problems, so it needs to be monitored in bacterial strains in various environments as a strategy to combat resistant bacteria [14].

Based on the above-mentioned considerations, the aim of our study was to detect the presence of Enterococcus sp. from sheep and goat cheese produced on a farm located in the border area of Slovakia with Hungary and, subsequently, determine the antimicrobial resistance of bacteria found in these products. The cheeses tested by us belong to the group of so-called RTE (ready-to-it) cheeses. We also include bryndza among such products. Bryndza is a typical Slovak cheese made from raw milk with no special starter culture [15].

Although there have been numerous studies on antimicrobial resistance, there is not currently enough information from local studies on produced milk as well as products from milk at farm level in selected parts of the studied territory. In addition, most studies have addressed the prevalence of antimicrobial resistance in enterococci in cow's milk products, but not the antimicrobial resistance of enterococci in sheep's and goat's milk products. This study contributes to the acquisition of knowledge in this area.

\section{Materials and Methods}

\subsection{Isolation and Identification of Strains}

From May to September 2020, we isolated enterococcal strains from sheep $(n=10)$ and goat $(n=10)$ cheese samples. The cheeses were made from unpasteurized milk without the addition of an initial cheese culture and matured for 30 days. Subsequently, a stock suspension and decimal dilutions were prepared from all tested samples according to ISO norm [16].

Enterococcal isolates from the examined samples were isolated according to Koreňová et al. [17]. Subsequently, based on the characteristic appearance, typical colonies of bacteria were used for identification by PCR reaction.

The DNA was isolated from enterococcal strains according Hein et al. [18]. The PCR method was used to identify the genus of Enterococcus according to Ke et al. [19] and Martineau et al. [20]. As an internal control for PCR, primer sequences derived from the bacterial $16 S$ rRNA gene and primers derived from the tuf gene were used to obtain a specific sequence for the genus Enterococcus sp. Each primer was synthesized in Generi Biotech s.r.o. (Table S1; Hradec Králové, Czech Republic).

The PCR protocol was optimized as follows: initial denaturation at $95^{\circ} \mathrm{C}$ for $12 \mathrm{~min}$, with the next step including 30 cycles (denaturation at $95^{\circ} \mathrm{C}$ for $20 \mathrm{~s}$, annealing at $55^{\circ} \mathrm{C}$ for $60 \mathrm{~s}$, extension at $72{ }^{\circ} \mathrm{C}$ for $2 \mathrm{~min}$ ). Final extension was performed at $72{ }^{\circ} \mathrm{C}$ for $10 \mathrm{~min}$. The HotFirepol ${ }^{\circledR}$ Mastermix (Ecoli s.r.o., Bratislava, Slovakia) was used in the PCR reaction. PCR products were visualized in agarose gel with Goldview ${ }^{\mathrm{TM}}$ Nucleic acid stain (Beijing SBS Genetech Co. LTD., Beijing, China) by using the MiniBIS Pro ${ }^{\circledR}$, (DNR Bio-Imaging system Ltd., Neve Yamin, Israel).

Identification using MALDI-TOF MS was performed using Flex Analysis software, version 3.0 on an Ultraflex III instrument and BioTyper software, version 1.1 (Bruker Daltonics, Billerica, MA, USA). For the most accurate analysis, individual samples were prepared by an extraction procedure using ethanol and formic acid [21]. The samples were analyzed in cooperation with the Institute of Animal Physiology of the Slovak Academy of Sciences in Košice. 


\subsection{Assessment of Antibiotic Sensitivity}

The susceptibility of isolated bacterial strains to selected antibiotics and multi-drug resistance (MDR) was determined by the agar dilution method (ADM) according to the procedure described by CLSI document [22]. MDR was defined as acquired non-susceptibility to at least one agent in three or more antimicrobial categories [22]. ADM was performed on Petri dishes with Müeller-Hinton agar (Hi-Media, Mumbai, India) in duplicate. Test plates containing different concentrations of antibiotics were used for the determination of minimum inhibitory concentrations (MICs). After inoculation, these plates were incubated at $37^{\circ} \mathrm{C}$ for $24 \mathrm{~h}$. Detected MICs were evaluated according to CLSI document [22].

In determining the MICs, assay plates were used with the following final concentrations of antibiotics on Enterococcus sp.: ciprofloxacin (CIP) $0.5-8.0 \mathrm{mg} / \mathrm{L}$; doxycycline (DO) 2.0-32.0 mg/L; erythromycin (E) 0.25-16.0 mg/L; nitrofurantoin (F) $16.0-256.0 \mathrm{mg} / \mathrm{L}$; levofloxacin (L) $1.0-16.0 \mathrm{mg} / \mathrm{L}$; minocycline $(\mathrm{MH}) 2.0-32.0 \mathrm{mg} / \mathrm{L}$; rifampicin (RD) $0.5-8.0 \mathrm{mg} / \mathrm{L}$; teicoplanin (TEC) $4.0-64.0 \mathrm{mg} / \mathrm{L}$; vancomycin (VAN) $2.0-64.0 \mathrm{mg} / \mathrm{L}$.

MIC breakpoints to determine antibiotic resistance were as follows [22]: $\mathrm{CIP} \geq 4 \mathrm{mg} / \mathrm{L} ; \mathrm{DO} \geq 16 \mathrm{mg} / \mathrm{L} ; \mathrm{E} \geq 8 \mathrm{mg} / \mathrm{L} ; \mathrm{F} \geq 128 \mathrm{mg} / \mathrm{L} ; \mathrm{L} \geq 8 \mathrm{mg} / \mathrm{L} ;$ $\mathrm{MH} \geq 16 \mathrm{mg} / \mathrm{L} ; \mathrm{RD} \geq 4 \mathrm{mg} / \mathrm{L} ; \mathrm{TEC} \geq 32 \mathrm{mg} / \mathrm{L} ; \mathrm{VAN} \geq 32 \mathrm{mg} / \mathrm{L}$.

After detecting the phenotypic manifestation of antimicrobial resistance in enterococci, the following genetic determinants of resistance were detected: vanA, $\operatorname{erm} A$, ermB, ermC, and $m s r C$ (Table S1). The PCR reaction conditions were the same (except for the annealing temperature; Table S1) for the genus identification of the isolates above. The obtained gene sequences from the studied strains used in this work were submitted to the GenBank-EMBL database. The obtained DNA sequences were searched for homology to those available at the GenBank-EMBL database using the BLAST program (NCBI software package).

Enterococcus (E.) faecalis CCM 4224 (Czech Collection of Microorganisms, Brno, Czech Republic) was used in this study as a reference strain for the PCR method and ADM.

\subsection{Statistical Analysis}

Significant difference analysis of isolates of Enterococcus sp. antibiotic resistance was made by the odds ratio (OR) test conducted with MedCalc Statistical Software version 19.2.6 (MedCalc Software, Ostend, Belgium) according to Regecová et al. [23]. A confidence interval was set to $p<0.05$ at $95 \%$.

\section{Results}

By microbiological culture examination of individual cheese samples and subsequent identification of isolates by PCR method, 110 isolates of Enterococcus sp. were obtained. Subsequently, we performed species identification of the 110 examined isolates by MALDI-TOF MS method; we identified 3 bacterial species, namely, E. faecium (12 isolates: goat cheese8 isolates; sheep cheese -4 isolates), E. faecalis (28 isolates: goat cheese- 13 isolates; sheep cheese-15 isolates), E. durans (12 isolates: goat cheese- 8 isolates; sheep cheese- 4 isolates).

Identified isolates of Enterococcus sp. showed high antibiotic resistance to vancomycin (84.62\%; 44/52 isolates), teicoplanin ( $84.62 \% ; 44 / 52$ isolates), erythromycin $(76.92 \%$; $40 / 52$ isolates), and rifampicin ( $76.92 \% ; 40 / 52$ isolates). Lower antibiotic resistance was detected against nitrofurantoin $(46.15 \% ; 24 / 52$ isolates) and minocycline $(38.46 \%$; $20 / 52$ isolates). Individual AMR profiles of enterococci in sheep and goat cheese samples are shown in Figures 1 and 2. 
A

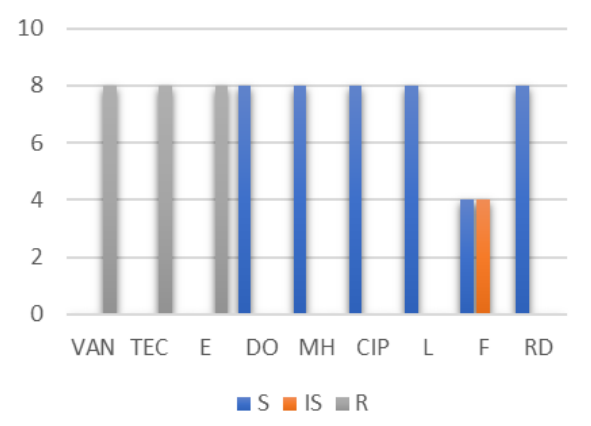

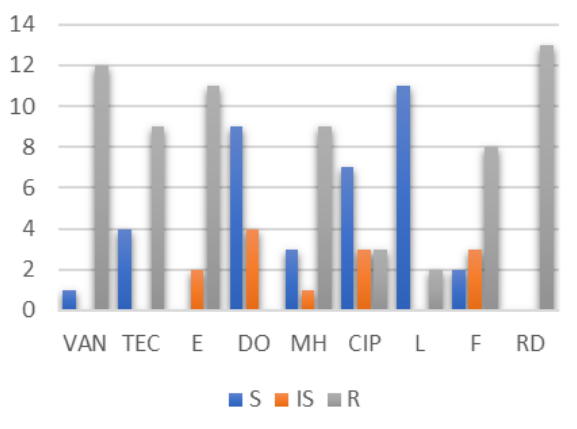

C

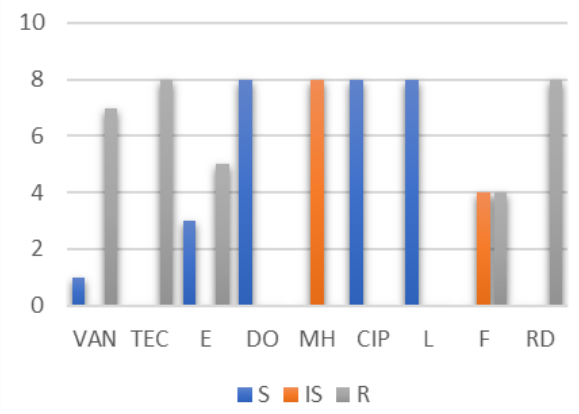

Figure 1. Number of resistant (R), intermediately resistant (IS), and susceptible (S) E. faecium $(n=8)$ (A), E. faecalis $(n=13)(\mathbf{B})$, and E. durans $(n=8)(\mathbf{C})$ in goat cheese samples. $n$ : number strains; VAN: vancomycin; TEC: teicoplanin; E: erythromycin; DO: doxycycline; MH: minocycline; CIP: ciprofloxacin; L: levofloxacin; F: nitrofurantoin; RD: rifampicin.

A

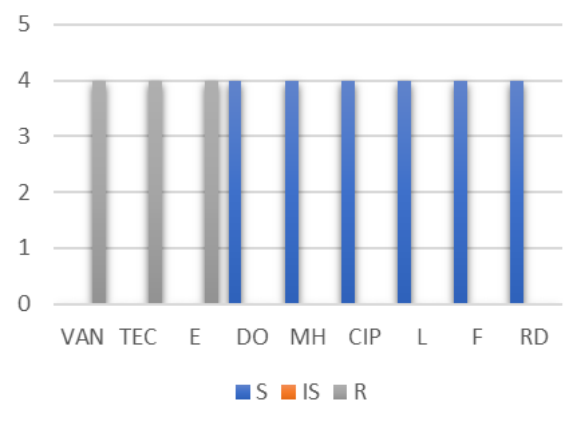

B

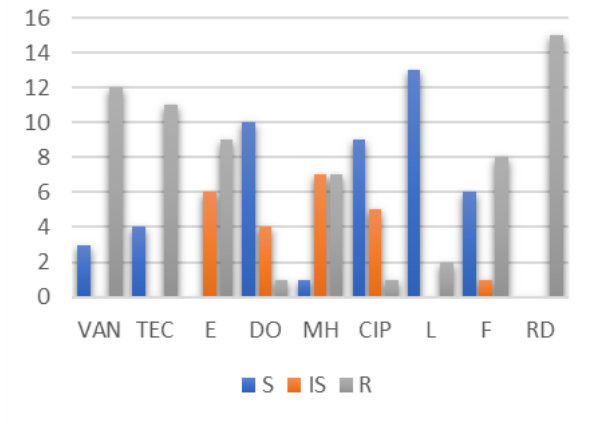

C

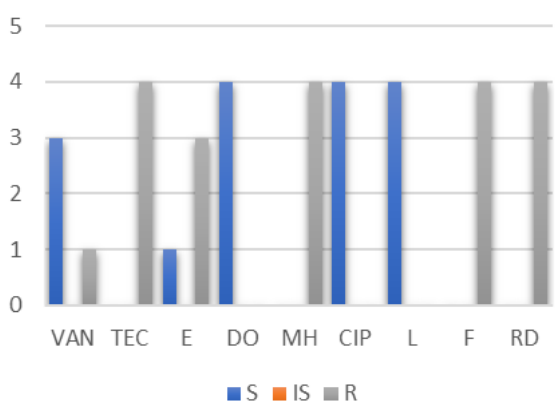

Figure 2. Number of resistant (R), intermediately resistant (IS), and susceptible (S) E. faecium $(n=4)$ $(\mathrm{A})$, E. faecalis $(n=15)(\mathbf{B})$, and E. durans $(n=4)(\mathrm{C})$ in sheep cheese samples. $n$ : number strains; VAN: vancomycin; TEC: teicoplanin; E: erythromycin; DO: doxycycline; MH: minocycline; CIP: ciprofloxacin; L: levofloxacin; F: nitrofurantoin; RD: rifampicin. 
For the antibiotic vancomycin at a concentration of $32.0 \mathrm{mg} / \mathrm{L}$, out of a total of 52 isolates of Enterococcus sp., 28 isolates (53.85\%) were resistant, while at a concentration of $64.0 \mathrm{mg} / \mathrm{L}, 16$ isolates $(30.77 \%)$ were resistant. The antibiotic teicoplanin at a concentration of $32.0 \mathrm{mg} / \mathrm{L}$ showed a number of resistant isolates (30; 57.67\%). At twice the concentration of the antibiotic teicoplanin $64.0 \mathrm{mg} / \mathrm{L}, 14$ isolates were resistant $(26.92 \%)$, a decrease of $53.33 \%$ compared to the dose of $32.0 \mathrm{mg} / \mathrm{L}$. The $p$ value of vancomycin and teicoplanin is significantly lower than the alpha, and this difference is statistically significant $(p<0.05)$. Resistance to the antibiotic erythromycin $(E)$ was determined from concentrations of $8.0 \mathrm{mg} / \mathrm{L}$ and $16.0 \mathrm{mg} / \mathrm{L}$. At a concentration of $8.0 \mathrm{mg} / \mathrm{L}, 31$ isolates were resistant $(59.62 \%)$. However, at a concentration of $16.0 \mathrm{mg} / \mathrm{L}$, only 9 isolates $(17.31 \%)$ were resistant. The odds ratio (OR) is 7.05, which demonstrates that there is a 7.05 times higher chance that an isolate shows resistance at a dose of $8.0 \mathrm{mg} / \mathrm{L}$ than at a dose of $16.0 \mathrm{mg} / \mathrm{L}(p<0.0001)$. For the antibiotic nitrofurantoin (F), the MIC was set at a cut-off value of $128.0 \mathrm{mg} / \mathrm{L}$ and $256.0 \mathrm{mg} / \mathrm{L}$. The results showed that 20 isolates $(38.46 \%)$ were resistant at a concentration of $128.0 \mathrm{mg} / \mathrm{L}$. A statistically significant decrease $(p<0.001)$ in the number of resistant isolates of enterococci $(7.69 \%$; 4 ) was found at a concentration of $256.0 \mathrm{mg} / \mathrm{L}$. Rifampicin-resistant strains had an MIC determined from 4.0 to $8.0 \mathrm{mg} / \mathrm{L}$. At a concentration of $4.0 \mathrm{mg} / \mathrm{L}, 29$ isolates were resistant $(55.77 \%)$, while at a concentration of $8.0 \mathrm{mg} / \mathrm{L}, 11$ isolates $(21.15 \%)$ were resistant $(p<0.001)$. All other antibiotics, doxycycline (DO), minocycline (MH), ciprofloxacin (CIP), and levofloxacin (L), did not show a statistically significant change $(p>0.05)$ in the number of resistant enterococci at different antibiotic concentrations (Table 1 ).

Table 1. Number of resistant ${ }^{\circledR}$, intermediately susceptible (IS), and susceptible (S) species of Enterococcus sp.

\begin{tabular}{|c|c|c|c|c|c|c|c|c|c|c|}
\hline & АТВ & VAN & TEC & $\mathbf{E}$ & DO & MH & CIP & $\mathbf{L}$ & $\mathbf{F}$ & RD \\
\hline \multirow{14}{*}{$\begin{array}{c}\mathrm{MIC} \\
(\mathrm{mg} / \mathrm{L})\end{array}$} & 0.25 & - & - & 3 & - & - & - & - & - & - \\
\hline & 0.5 & - & - & 1 & - & - & 32 & - & - & 5 \\
\hline & 1 & - & - & 2 & - & - & 8 & 27 & - & 7 \\
\hline & 2 & 5 & - & 2 & 28 & 6 & 8 & 21 & - & - \\
\hline & 4 & 3 & 4 & 4 & 15 & 10 & 3 & - & - & $29^{a}$ \\
\hline & 8 & - & 4 & $31^{a}$ & 8 & 16 & 1 & 3 & - & $11^{\mathrm{b}}$ \\
\hline & 16 & - & - & $9^{b}$ & 1 & 11 & - & 1 & 7 & - \\
\hline & 32 & $28^{a}$ & $30^{a}$ & - & - & 9 & - & - & 9 & - \\
\hline & 64 & $16^{b}$ & $14^{b}$ & - & - & - & - & - & 12 & - \\
\hline & 128 & - & - & - & - & - & - & - & $20^{a}$ & - \\
\hline & 256 & - & - & - & - & - & - & - & $4^{b}$ & - \\
\hline & OR & 2.6250 & 3.7013 & 7.0529 & 3.0583 & 1.2818 & 3.1224 & 3.1224 & 7.5000 & 4.6996 \\
\hline & $95 \%$ CI & $1.18-5.86$ & $1.62-8.43$ & $2.85-17.47$ & & $0.48-3.41$ & $0.31-31.0$ & $0.31-31.0$ & 2.34-23.99 & $1.99-11.12$ \\
\hline & $p$ value & $<0.05$ & $<0.05$ & $<0.0001$ & $>0.05$ & $>0.05$ & $>0.05$ & $>0.05$ & $<0.001$ & $<0.001$ \\
\hline
\end{tabular}

a,b Means within a row different superscript differ $(p<0.05)$; $95 \%$ CI: confidence interval estimate/chance of being resistant at a given ATB concentration; ATB: antibiotics; MIC: minimal inhibitory concentration; VAN: vancomycin; TEC: teicoplanin; E: erythromycin; DO: doxycycline; MH: minocycline; CIP: ciprofloxacin; L: levofloxacin; F: nitrofurantoin; RD: rifampicin. Black lines represent the breakpoints that categorize enterococci as "resistant".

The occurrence of multidrug-resistant strains is of great importance in the spread of antimicrobial resistance. In a series of tests, multidrug-resistant strains were confirmed in $80 \%$ of a total of 52 strains. Specifically, multidrug resistance to five antibiotics simultaneously (VA-TEC-E-F-RD) was most frequently confirmed in E. durans. In species E. faecalis, multidrug resistance to four antibiotics simultaneously (VA-TEC-F-RD) was observed. In three strains of $E$. faecalis, multidrug resistance to eight antibiotics simultaneously was also confirmed, namely VA-TEC-E-MH-CIP-L-F-RD. In E. faecium, resistance to three antibiotics simultaneously (VA-TEC-E) was confirmed.

All 40 erythromycin-resistant isolates were tested for $\operatorname{ermA}$, ermB, erm C, and $m s r C$ genes [24-27]. Among erythromycin-resistant isolates, $\operatorname{ermB}(n=23)$ was the most common resistance gene, followed by ermA $(n=9)$, $\operatorname{ermC}(n=2)$, and $\operatorname{msrC}(n=1)$, of which one E. faecium isolate, two E. faecalis isolates, and one E. durans isolate had ermB and ermA, and 
one E. faecalis isolate had ermA and $m s r C$. The presence of ermB, erm $A$, and erm $C$ was also detected in one $E$. faecalis isolate. The phenotypic expression of erythromycin resistance was confirmed in all isolates in which the presence of at least one gene encoding erythromycin resistance was confirmed (Figure S2). In addition to the detection of genes encoding erythromycin resistance, the presence of the vanA gene, which encodes vancomycin resistance, was detected in the test isolates. Teicoplanin resistance was also phenotypically manifested in 40 vancomycin-resistant isolates, indicating a phenotype of vanA isolates. For these isolates, the presence of the vanA gene was confirmed in 21 isolates by PCR. Specifically, the phenotype and genotype of van $A$ were confirmed in 6 isolates in E. faecium isolates, in 11 isolates in E. faecalis, and in 4 isolates in E. durans. The ermA, ermB, ermC, and vanA resistance genes were also detected in one $E$. faecalis isolate that had confirmed multidrug resistance to VA-TEC-E-MH-CIP-L-F-RD. In one E. faecium isolate that showed phenotypic resistance to VAN, TEC, E, ermB, ermA, and vanA genes were detected. At the same time, the presence of the ermB, erm $A$, and $\operatorname{van} A$ genes was detected in the isolate phenotypically evaluated as multidrug resistant to VA-TEC-E-F-RD. The above multidrug-resistant isolates reported a vanA phenotype.

\section{Discussion}

Enterococcus species are ubiquitous bacterial. The most common include Enterococcus faecium, Enterococcus durans, and Enterococcus faecalis [28]. Biendo et al. [29], in turn, determined that more than half of the analyzed dairy products intended for direct consumption contained Enterococcus bacteria, and E. faecium was observed to be the predominant species. It has previously been reported that E. faecium (52.6\%), E. durans (17.7\%), E. hirae (16.4\%), and E. faecalis (12.8\%) are also common in Serbian cheeses [30]. The proportion of E. faecium $(57 \%)$, E. durans (22\%) and E. faecalis (16\%) in Slovak bryndza cheese were set [31]. Jamet et al. [32] evaluated 126 samples of soft, semi-hard, and hard traditional French cheeses and observed a high prevalence of $E$. faecalis isolates (81\%) compared to E. faecium $(9.5 \%)$ and E. durans $(7.7 \%)$ Similar results were reported by Oguntoyinbo and Okueso [33] in a study with 30 samples of traditional fermented dairy products (wara and nunu) made from unpasteurized milk in Nigeria. The occurrence of resistant $E$. faecalis in sheep's milk has been confirmed by several studies [34-36].

The high level of resistant enterococcal contamination of the samples may be due to the actual contamination of the milk as well as the fact that these bacteria are resistant to pasteurization temperature and are resistant to various substrates and developmental conditions (temperatures, $\mathrm{pH}$, salinity, etc.) [29,32]. Previous studies in Turkey have reported that the prevalence of enterococci in cheese samples ranges between $62 \%$ and $99 \%$. The study by Sanlibaba and Senturk in 215 traditional cheese samples identified $99.1 \%$ enterococcal isolates that were highly resistant to nalidixic acid (100\%), kanamycin (98.6\%), and rifampicin $(78.4 \%)$, and were resistant to ampicillin, ciprofloxacin, erythromycin, tetracycline, penicillin G, chloramphenicol, gentamycin, and streptomycin [37,38]. Enterococci are able to acquire antimicrobial resistance through horizontal gene transfer [39].

The resistance profile of Enterococcus species according to [36] is as follows: erythromycin (49.2\%); vancomycin (37.3\%); and tetracycline (45.8\%). Concurrently, the detected occurrence of antibiotic resistance genes in theses tested enterococci is as follows: ermA $44.8 \%$, vanA $63.6 \%$, tet $A 51.9 \%$, tet $M 55.6 \%$, ermB $13.8 \%$, and van $B 22.7 \%$. This study may reveal that RTE food products may be reservoirs of detectable enterococci such as E. casseliflavus, E. durans, E. hirae, E. gallinarum [36].

Jamet et al. [32] noted in their work that enterococci may be present in cheese as a possible intermediate for the transmission of multidrug resistance. In Gaglio et al. [5], out of a total of 40 strains, resistance was highest for ERY (21 strains) and for CIP (14 strains). No resistance to penicillin, ampicillin, vancomycin, levofloxacin, linezolid, or gentamicin was observed. A total of 31 enterococci from 40 strains showed resistance to at least one antimicrobial compound. Three strains showed a multidrug-resistant phenotype (resistance to at least three antimicrobials). The study confirmed that most dairy enterococci are 
vectors for the spread of genes for antimicrobial resistance and virulence. Cheeses therefore represent an interesting environment for deepening studies on the risk and contribution of enterococci in fermented foods in terms of their qualified presumption of safety (QPS).

The presence of resistant enterococci in cheeses was also confirmed by our study. The antimicrobial cohesion found may vary between species of enterococci, therefore species identification of the tested isolates is required. Laser absorption/ionization matrix mass spectrometry (MALDI-TOF MS) has enabled the rapid and accurate identification of many microorganisms in the last decade $[40,41]$.

A previous study [42] confirmed the presence of E. durans, E. faecium, and E. faecalis in the examined cheeses by the MALDI-TOF method, as we did in our study.

Enterococci may pose a public health problem due to their resistance to cephalosporins, lincosamides, penicillins, and low levels of aminoglycosides [4]. Enterococci isolated from dairy products also express a similar resistant gene profile as the profile of enterococci isolated from human infections [5]. E. durans is a bacterium susceptible to vancomycin, ampicillin, tetracycline, chloramphenicol, and aminoglycosides [7]. However, this species is in some cases resistant to erythromycin. Resistance to erythromycin, a representative of macrodile antibiotics, is a matter of concern because macrodiles are a common substitute for individuals allergic to penicillin $[43,44]$.

One type is associated with the mechanism of macrolide resistance by methylation of $23 \mathrm{~S}$ rRNA, with the methylating enzyme mainly encoded by erm genes [45]. In a previous study [46], the $\mathrm{ermB}$ gene associated with methylation represented $96.0 \%$ of all macrolide-resistant $E$. faecalis. Out of 143 isolates, 140 were ermB positive.

Chajecka-Wierzchowska et al. [47] in their study confirmed a high incidence of erythromycin-resistant strains $(14.3 \%)$. Resistance to macrolides was only associated with the presence of the ermB and ermA genes in individual strains. Conjugative mobile genetic elements were identified in $15.3 \%$ of strains. Regardless of the species, erythromycin testing was associated with the presence of the constitutive $\mathrm{erm} B$ gene. A high percentage of strains also contained either a combination of the erm $A$ and ermB genes, or only the erm $A$ gene [47].

In addition to testing the erythromycin susceptibility of the isolates, the study also detected resistance to vancomycin, which was confirmed in $84.7 \%$ of the total 52 isolates tested. In a study by Chajecka-Wierzchowska et al. [47], two isolated strains of E. faecalis were resistant to this antibiotic; high MIC values of these strains (>259 $\mathrm{\mu g} / \mathrm{mL}$ vancomycin) are a cause for concern. Their genotypic analysis did not reveal the presence of the vanA or van $B$ genes; therefore, they hypothesized that vancomycin resistance may be encoded by other genes not analyzed in this study, such as vanD, vane, or van G. Similar observations were made by Gomes et al. [48].

Historically, vancomycin-resistant isolates have been identified in the out-of-hospital region of the country, where avoparcin has been approved for use as a growth stimulator [49]. In Europe, the prevalence of vancomycin-resistant isolates from animal-based food products has been steadily declining since avoparcin was banned in animal production [50,51]. Previous studies have shown that enterococci isolated from RTE food can transmit resistance genes of vancomycin to $E$. faecalis strains. It was found that more than $70 \%$ of the tested strains were able to conjugate the transfer of at least one of the antibiotic resistance genes $[47,52,53]$.

Similarly, in Pieniz et al. [54], in addition to vancomycin sensitivity analyses, E. durans was evaluated for the presence of resistance to the vancomycin gene, where the presence of the $\operatorname{Van} A, \operatorname{van} C 1$, and $\operatorname{van} C 2$ genes was not confirmed by PCR in the tested isolates. The presence of vancomycin resistance genes in strains present in animal feed is essential because the antibiotic is not metabolized by animals and therefore remains in an active form in the gut [55] that promotes vancomycin-resistant enterococci (VRE). In Europe, nonhospitalized patients, animals, and the environment are often the source of VRE (especially the vanA genotype) [56,57].

In the last two decades, the prevalence of VRE strains has been increasing in severe enterococcal infections that are difficult to treat. The VRE was first reported by [58]. 
Subsequently, the occurrence of VRE has been reported in many countries around the world. This is a particularly big problem in the Western world [59].

In a study by Perin et al. [60], no isolate presented a positive result for the vanB gene. In contrast, four Enterococcus isolates presented positive results for the vanA gene but tested negative according to vancomycin resistance phenotype assay. In our study of 48 isolates resistant to phenotypic vancomycin, only 21 isolates showed the presence of the vanA gene. This suggests that in other phenotypic VREs, resistance may be related to other typical gene resistances, such as $\operatorname{van} B, \operatorname{van} C, \operatorname{van} D$, vanE, or van $G$. Vancomycin resistance occurs in isolates due to the transmission of genetic determinants of resistance. Vancomycin-resistant enterococci have been implicated as a common cause of nosocomial infections [61-63].

In our study, the vanA phenotype was most frequently confirmed based on the VRE phenotype and genotype (91.6\%). VanA glycopeptide resistance is characterized by acquired inducible resistance to both vancomycin and teicoplanin, while the VanB phenotype is characterized by variable levels of vancomycin resistance but sensitivity to teicoplanin $[64,65]$. Over the last 5 years, vancomycin-resistant enterococci (VRE) with the van $A$ genotype that are susceptible to teicoplanin (i.e., having the vanB phenotype and the van $A$ genotype) have been increasingly occurring in Asia [66-68].

In addition to the aforementioned antibiotics, the present study focused on the detection of resistance to other antibiotics. High percentage of resistance was noted in E. faecalis to rifampicin $(100 \%)$, vancomycin $(85.7 \%)$, teicoplanin $(71.4 \%)$, erythromycin $(71.4 \%)$, minocycline $(57.1 \%)$, nitrofurantoin $(57.1 \%)$, ciprofloxacin $(14.3 \%)$, and levofloxacin $(14.3 \%)$. E. durans showed resistance to rifampicin (100\%), teicoplanin (100\%), vancomycin $(66.7 \%)$, erythromycin $(66.7 \%)$, nitrofurantoin $(66.7 \%)$, and minocycline $(33.3 \%)$, and E. faecium showed resistance to vancomycin, teicoplanin, and erythromycin (100\%). In a study by Chajecka-Wierzchowska et al., [47], the highest percentage of resistance detected among the analyzed Enterococcus strains was to erythromycin (14.3\%), followed by tetracycline (11.6\%) and rifampicin (8.7\%). The percentage of strains resistant to the remaining antibiotics was determined to be from $3.2 \%$ to $1.1 \%$, and none was teicoplanin resistant. Two strains of E. faecalis were resistant to vancomycin, the drug of last resort against severe Gram-positive bacterial infections (MIC $>256 \mathrm{mg} / \mathrm{mL}$ ); however, no vanA or vanB genes were identified. Genes encoding vancomycin resistance have only been reported in E. casseliflavus and E. gallinarum, and these have been associated with natural bacterial vancomycin resistance encoded in the vanC1 and vanC2 or C3 genes. In total, 26 (13.75\%) multidrug-resistant strains and 23 different multidrug-resistant phenotypes were identified. Three E. faecalis isolates were resistant to linezolid, an antibiotic approved for use in 2000. Phenotypes of resistance to various drugs were observed for both E. faecalis, E. faecium, and other enterococci species isolated in the mentioned study.

The results of our study confirm the occurrence of resistant and multidrug-resistant enterococci in cheese samples. The MALDI-TOF mass spectrometry method used in the study to identify individual species of enterococci has a lower discriminant index in determining the clonality of strains compared to molecular methods, which may lead to testing of the same strains. This could be the cause of the higher degree of resistance to most of the tested antimicrobials; however, our percentage results of antimicrobial resistance of individual antibiotics correlate with the above studies.

In general, views on enterococci are diverse and ambiguous. Some countries classify them as cultures beneficial to cheese production, however, on the other hand, we can classify them as bacteria that cause health problems. Resistance to antibiotics in terms of pathogenicity, as well as the production of biogenic amines, designates enterococci among undesirable microorganisms in food [42].

\section{Conclusions}

Based on the above results, the incidence of antimicrobial resistance in enterococcal isolates from sheep and goat cheeses was determined. At the same time, the presence of genes determining resistance to erythromycin and vancomycin was confirmed in the 
isolates. The presence of resistant enterococci indicates the risk of the spread of antibiotic resistance in foodstuffs of animal origin in a selected part of the border area of Slovakia with Hungary.

Supplementary Materials: The following are available at https://www.mdpi.com/article/10.339 0/foods10081844/s1: Table S1: Descriptions of primers used in this study; Figure S1: Workflow of detection of resistant enterococci from cheeses samples; Figure S2: Heatmap demonstration of the presence and absence of genes across species.

Author Contributions: Conceptualization: J.V.; Methodology: J.V. and I.R.; Software: M.K.; Formal analysis: E.D.; nvestigation and data curation: S.M. and E.D.; Writing-original draft preparation: J.V.; Writing-review and editing: I.R.; Supervision: I.R. and E.D.; Project administration and funding acquisition: M.V. and J.M. All authors have read and agreed to the published version of the manuscript.

Funding: This work was supported by the Ministry of Education, Science, Research and Sport of the Slovak Republic under the grant KEGA 007UVLF-4/2020 Innovation of milk and milk products hygiene and technology education at the University of Veterinary Medicine and Pharmacy in Košice.

Data Availability Statement: The data presented in this study are available upon request from the corresponding author.

Conflicts of Interest: The authors declare no conflict of interest.

\section{References}

1. Torres, C.; Alonso, C.A.; Ruiz-Ripa, L.; León-Sampedro, R.; Del Campo, R.; Coque, T.M. Antimicrobial resistance in Enterococcus spp. of animal origin. Microbiol. Spectr. 2018, 4. [CrossRef]

2. Giraffa, G. Functionality of enterococci in dairy products. Int. J. Food Microbiol. 2003, 88, 215-222. [CrossRef]

3. İspirli, H.; Demirbaş, F.; Dertli, E. Characterization of functional properties of Enterococcus spp. isolated from Turkish white cheese. LWT 2017, 75, 358-365. [CrossRef]

4. Hammad, A.M.; Hassan, H.A.; Shimamoto, T. Prevalence, antibiotic resistance and virulence of Enterococcus spp. in Egyptian fresh raw milk cheese. Food Control 2015, 50, 815-820. [CrossRef]

5. Gaglio, R.; Couto, N.; Marques, C.; Lopes, M.D.F.S.; Moschetti, G.; Pomba, C.; Settanni, L. Evaluation of antimicrobial resistance and virulence of enterococci from equipment surfaces, raw materials, and traditional cheeses. Int. J. Food Microbiol. 2016, 236, 107-114. [CrossRef]

6. Hussein, W.E.; Abdelhamid, A.G.; Rocha-Mendoza, D.; García-Cano, I.; Yousef, A.E. Assessment of safety and probiotic traits of Enterococcus durans OSY-EGY, isolated from Egyptian artisanal cheese, using comparative genomics and phenotypic analyses. Front. Microbiol. 2020, 11, 3094. [CrossRef] [PubMed]

7. Russo, N.; Caggia, C.; Pino, A.; Coque, T.M.; Arioli, S.; Randazzo, C.L. Enterococcus spp. in ragusano PDO and pecorino siciliano cheese types: A snapshot of their antibiotic resistance distribution. Food Chem. Toxicol. 2018, 120, 277-286. [CrossRef]

8. Nueno-Palop, C.; Narbad, A. Probiotic assessment of Enterococcus faecalis CP58 isolated from human gut. Int. J. Food Microbiol. 2011, 145, 390-394. [CrossRef]

9. Lebreton, F.; Willems, R.J.L.; Gilmore, M.S. Enterococcus diversity, origins in nature, and gut colonization. In Enterococci: From Commensals to Leading Causes of Drug Resistant Infection; Gilmore, M.S., Clewell, D.B., Ike, Y., Eds.; Massachusetts Eye and Ear Infirmary: Boston, MA, USA, 2014; pp. 5-63.

10. Miller, W.R.; Munita, J.M.; Arias, C.A. Mechanisms of antibiotic resistance in enterococci. Expert Rev. Anti. Infect. Ther. 2014, 12, 1221-1236. [CrossRef]

11. Arias, C.A.; Murray, B.E. The rise of the Enterococcus: Beyond vancomycin resistance. Nat. Rev. Microbiol. 2012, 10, 266-278. [CrossRef] [PubMed]

12. Tenover, F.C.; McDonald, L.C. Vancomycin resistant staphylococci and enterococci: Epidemiology and control. Curr. Opin. Infect. Dis. 2005, 18, 300-305. [CrossRef]

13. Kristich, C.J.; Rice, L.B.; Arias, C.A. Enterococcal infection-treatment and antibiotic resistance. In Enterococci: From Commensals to Leading Causes of Drug Resistant Infection; Gilmore, M.S., Clewell, D.B., Ike, Y., Shankar, N., Eds.; Massachusetts Eye and Ear Infirmary: Boston, MA, USA, 2014.

14. Tyson, G.H.; Sabo, J.L.; Rice-Trujillo, C.; Hernandez, J.; McDermott, P.F. Whole-genome sequencing based characterization of antimicrobial resistance in Enterococcus. Pathog. Dis. 2018, 76, fty018. [CrossRef] [PubMed]

15. Vrabec, M.; Lovayová, V.; Dudriková, K.; Gallo, J.; Dudriková, E. Antibiotic resistance and prevalence of Enterococcus spp. and Escherichia coli isolated from bryndza cheese. Ital. J. Anim. Sci. 2015, 14, 3968. [CrossRef] 
16. Iso 6887-5:2010. Microbiology of Food and Animal Feeding Stuffs. Preparation of Test Samples, Initial Suspension and Decimal Dilutions for Microbiological Examination. Part 5 Specific Rules for the Preparation of Milk and Milk Products; Slovak Standards Institute: Bratislava, Slovakia, 2010.

17. Koreňová, J.; Lopašovská, J.; Kuchta, T. Comparison of three microtitre plate-based methods for quantification of biofilm formation ability of bacteria contaminating food technologies. J. Food Nutr. Res. 2008, 47, 100-104. [CrossRef]

18. Hein, I.; Jorgensen, H.J.; Loncarevic, S.; Wagner, M. Quantification of Staphylococcus aureus in unpasteurised bovine and caprine milk by real-time PCR. Res. Microbiol. 2005, 156, 554-563. [CrossRef] [PubMed]

19. Ke, D.; Picard, F.J.; Martineau, F.; Ménard, C.; Roy, P.H.; Ouellette, M.; Bergeron, M.G. Development of a PCR assay for rapid detection of enterococci. J. Clin. Microbiol. 1999, 37, 3497-3503. [CrossRef] [PubMed]

20. Martineau, F.; Picard, F.J.; Roy, P.H.; Ouellette, M.; Bergeron, M.G. Species-specific and ubiquitous DNA-based assays for rapid identification of Staphylococcus epidermidis. J. Clin. Microbiol. 1996, 34, 2888-2893. [CrossRef] [PubMed]

21. Brucker Daltonics, MALDI Biotyper 2.0. Software for Microorganism Identification and Classification User Manual; Bruker Scientific LLC: Billerica, MA, USA, 2008.

22. CLSI document M100-S30. Performance Standards for Antimicrobial Susceptibility Testing; Thirtieth Informational Supplement; Clinical and Laboratory Standards Institute: Wayne, PA, USA, 2020.

23. Regecová, I.; Výrostková, J.; Zigo, F.; Gregová, G.; Kováčová, M. Detection of antimicrobial resistance of bacteria Staphylococcus chromogenes isolated from sheep's milk and cheese. Antibiotics 2021, 10, 570. [CrossRef] [PubMed]

24. Martín-Platero, A.M.; Valdivia, E.; Maqueda, M.; Martínez-Bueno, M. Characterization and safety evaluation of enterococci isolated from Spanish goats' milk cheeses. Int. J. Food Microbiol. 2009, 132, 24-32. [CrossRef]

25. Di Cesare, A.; Luna, G.M.; Vignaroli, C.; Pasquaroli, S.; Tota, S.; Paroncini, P.; Biavasco, F. Aquaculture can promote the presence and spread of antibiotic-resistant Enterococci in marine sediments. PLoS ONE 2013, 8, e62838. [CrossRef]

26. Sutcliffe, J.; Grebe, T.; Tait-Kamradt, A.; Wondrack, L. Detection of erythromycin-resistant determinants by PCR. Antimicrob. Agents Chemother. 1996, 40, 2562-2566. [CrossRef] [PubMed]

27. Singh, K.V.; Malathum, K.; Murray, B.E. Disruption of an Enterococcus faecium species-specific gene, a homologue of acquired macrolide resistance genes of Staphylococci, is associated with an increase in macrolide susceptibility. Antimicrob. Agents Chemother. 2001, 45, 263-266. [CrossRef]

28. Hanchi, H.; Mottawea, W.; Sebei, K.; Hammami, R. The genus Enterococcus: Between probiotic potential and safety concerns-an update. Front. Microbiol. 2018, 9, 1791. [CrossRef] [PubMed]

29. Biendo, M.; Adjide, C.; Castelain, S.; Belmekki, M.; Rousseau, F.; Slama, M.; Ganry, O.; Schmi, J.L.; Eb, F. Molecular characterization of glycopeptide-resistant enterococci from hospitals of the picardy region (France). Int. J. Microbiol. 2010, 2020, 150464. [CrossRef]

30. Bulajić, S.; Tambur, Z.; Opacić, D.; Miljković-Selimović, B.; Doder, R.; Cenić-Milošević, D. Characterization of antibiotic resistance phenotypes and resistance genes in Enterococcus spp. isolated from cheeses. Arch. Biol. Sci. 2015, 67, 139-146. [CrossRef]

31. Belicová, A.; Križková, L.; Krajčovič, J.; Jurkovič, D.; Sojka, M.; Ebringer, L.; Dušinský, R. Antimicrobial susceptibility of Enterococcus species isolated from Slovak Bryndza cheese. Folia Microbiol. 2007, 52, 115-119. [CrossRef]

32. Jamet, E.; Akary, E.; Poisson, M.A.; Chamba, J.F.; Bertrand, X.; Serror, P. Prevalence and characterization of antibiotic resistant Enterococcus faecalis in French cheeses. Food Microbiol. 2012, 31, 191-198. [CrossRef] [PubMed]

33. Oguntoyinbo, F.A.; Okueso, O. Prevalence, distribution and antibiotic resistance pattern among enterococci species in two traditional fermented dairy foods. Ann. Microbiol. 2013, 63, 755-761. [CrossRef]

34. Hershberger, E.; Oprea, S.F.; Donabedian, S.M.; Perri, M.; Bozigar, P.; Bertlett, P.; Zervos, M.J. Eology of antimicrobial resistance in enterococci of animal origin. J. Antimicrob. Chemother. 2005, 55, 127-130. [CrossRef] [PubMed]

35. Sanciu, G.; Marogna, G.; Paglietti, B.; Cappuccinelli, P.; Leori, G.; Rappelli, P. Outbreak of mastitis in sheep caused by multi-drug resistant Enterococcus faecalis in Sardinia, Italy. Epidemiol. Infect. 2013, 141, 582-584. [CrossRef]

36. Hollenbeck, B.L.; Rice, L.B. Intrinsic and acquired resistance mechanisms in enterococcus. Virulence 2012, 3, 421-569. [CrossRef]

37. Sanlibaba, P.; Senturk, E. Prevalence, characterization and antibiotic resistance of enterococci from traditional cheeses in Turkey. Int. J Food Prop. 2018, 21, 1955-1963. [CrossRef]

38. Muş, T.E.; Cetinkaya, F.; Cıbık, R.; Soyutemiz, G.E.; Simsek, H.; Coplu, N. Antibiotic resistance profiles of enterococci from foods of animal origin in Turkey. Acta Vet. Hung. 2017, 65, 461-467. [CrossRef]

39. Raza, T.; Ullah, S.R.; Mehmood, K.; Andleeb, S. Vancomycin resistant Enterococci: A brief review. J Pak. Med. Assoc. 2018, 68, 768-772.

40. Cassagne, C.; Normand, A.C.; L'Ollivier, C.; Ranque, S.; Piarroux, R. Performance of MALDI-TOF MS platforms for fungal identification. Mycoses 2016, 59, 678-690. [CrossRef] [PubMed]

41. Böhme, K.; Antelo, S.C.; Fernández-No, I.C.; Quintela-Baluja, M.; Barros-Velázquez, J.; Cañas, B.; Calo-Mata, P. Chapter 15-Detection of Foodborne Pathogens Using MALDI-TOF Mass Spectrometry. Antimicrob. Food Packag. 2016, 203-214. [CrossRef]

42. Kačániová, M.; Kunova, S.; Horská, E.; Nagyová, L'.; Puchalski, C.; Haščík, P.; Terentjeva, M. Diversity of microorganisms in the traditional Slovak cheese. Potravin. Slovak J. Food Sci. 2019, 13, 532-537. [CrossRef]

43. Peters, J.; Mac, K.; Wichmann-Schauer, H.; Klein, G.; Ellerbroek, L. Species distribution and antibiotic resistance patterns of enterococci isolated from food of animal origin in Germany. Int. J. Food Microbiol. 2003, 88, 311-314. [CrossRef]

44. World Health Organization (WHO). 19th WHO Model List of Essential Medicines; World Health Organization Essential Medicines and Health Products: Geneva, Switzerland, 2015. 
45. Portillo, A.; Ruiz-Larrea, F.; Zarazaga, M.; Alonso, A.; Martinez, J.L.; Torres, C. Macrolide resistance genes in Enterococcus spp. Antimicrob. Agents Chemother. 2000, 44, 967-971. [CrossRef]

46. Kim, Y.B.; Seo, K.W.; Jeon, H.Y.; Lim, S.K.; Sung, H.W.; Lee, Y.J. Molecular characterization of erythromycin and tetracyclineresistant Enterococcus faecalis isolated from retail chicken meats. Poult. Sci. 2019, 98, 977-983. [CrossRef] [PubMed]

47. Chajęcka-Wierzchowska, W.; Zadernowska, A.; García-Solache, M. Ready-to-eat dairy products as a source of multidrug-resistant Enterococcus strains: Phenotypic and genotypic characteristics. J. Dairy Sci. 2020, 103, 4068-4077. [CrossRef]

48. Gomes, B.C.; Esteves, C.T.; Palazzo, I.C.; Darini, A.L.C.; Felis, G.E.; Sechi, L.A.; De Martinis, E.C. Prevalence and characterization of Enterococcus spp. isolated from Brazilian foods. Food Microbiol. 2008, 25, 668-675. [CrossRef] [PubMed]

49. Lauderdale, T.L.; McDonald, L.C.; Shiau, Y.R.; Chen, P.C.; Wang, H.Y.; Lai, J.F.; Ho, M. Vancomycin-resistant enterococci from humans and retail chickens in Taiwan with unique VanB phenotype-vanA genotype incongruence. Antimicrob. Agents Chemother. 2002, 46, 525-527. [CrossRef]

50. Casewell, M.; Friis, C.; Marco, E.; McMullin, P.; Phillips, I. The European ban on growth-promoting antibiotics and emerging consequences for human and animal health. J. Antimicrob. Chemother. 2003, 52, 159-161. [CrossRef] [PubMed]

51. Donabedian, S.M.; Perri, M.B.; Abdujamilova, N.; Gordoncillo, M.J.; Naqvi, A.; Reyes, K.C.; Bartlett, P. Characterization of vancomycin-resistant Enterococcus faecium isolated from swine in three Michigan counties. J. Clin. Microbiol. 2010, 48, 4156-4160. [CrossRef]

52. Eaton, T.J.; Gasson, M.J. Molecular screening of Enterococcus virulence determinants and potential for genetic exchange between food and medical isolates. Appl. Environ. Microbiol. 2001, 67, 1628-1635. [CrossRef] [PubMed]

53. Donabedian, S.M.; Thal, L.A.; Hershberger, E.; Perri, M.B.; Chow, J.W.; Bartlett, P.; Zervos, M.J. Molecular characterization of gentamicin-resistant enterococci in the United States: Evidence of spread from animals to humans through food. J. Clin. Microbiol. 2003, 41, 1109-1113. [CrossRef]

54. Pieniz, S.; de Moura, T.M.; Cassenego, A.P.V.; Andreazza, R.; Frazzon, A.P.G.; De Oliveira Camargo, F.A.; Brandelli, A. Evaluation of resistance genes and virulence factors in a food isolated Enterococcus durans with potential probiotic effect. Food Control. 2015, 51, 49-54. [CrossRef]

55. Yap, I.K.S.; Li, J.; Saric, J.; Martin, F.; Davies, H.; Wang, Y.; Wilson, I.; Nicholson, J.; Utzinger, J.; Marchesi, J.; et al. Metabolomic and microbiological analysis of the dynamic effect of vancomycin-induced gut microbiota modification in the mouse. J. Proteome Res. 2008, 7, 3718-3728. [CrossRef] [PubMed]

56. Bonten, M.J.; Willems, R.; Weistein, R.A. Vancomycin-resistant enterococci: Why are they here, and where do they come from? Lancet Infect. Dis. 2001, 1, 314-325. [CrossRef]

57. Mundy, L.M.; Sahm, D.F.; Gilmore, M. Relationships between enterococcal virulence and antimicrobial resistance. Clin. Microbiol. Rev. 2000, 13, 513-522. [CrossRef] [PubMed]

58. Uttley, A.H.; George, R.C.; Naidoo, J.; Woodford, N.; Johnson, A.P.; Collins, C.H.; Morrison, D.; Gilfillan, A.J.; Fitch, L.E.; Heptonstall, J. High-level vancomycin- resistant enterococci causing hospital infections. Epidemiol. Infect. 1989, 103, 173-181. [CrossRef] [PubMed]

59. Low, D.E.; Keller, N.; Barth, A.; Jones, R.N. Clinical prevalence, antimicrobial susceptibility, and geographic resistance patterns of enterococci: Results from the SENTRY Antimicrobial Surveillance Program, 1997-1999. Clin. Infect. Dis. 2001, 32, 133-145. [CrossRef] [PubMed]

60. Perin, L.M.; Miranda, R.O.; Todorov, S.D.; Franco, B.D.G.M.; Nero, L.A. Virulence, antibiotic resistance and biogenic amines of bacteriocinogenic lactococci and enterococci isolated from goat milk. Int. J. Food Microbiol. 2014, 185, 121-126. [CrossRef]

61. Ribeiro, T.; Abrantes, M.; Lopes, M.F.S.; Crespo, M.T.B. Vancomycin-susceptible dairy and clinical enterococcal isolates carry vanA and vanB genes. Int. J. Food Microbiol. 2007, 113, 289-295. [CrossRef] [PubMed]

62. Mathur, S.; Singh, R. Antibiotic resistance in food lactic acid bacteria-A review. Int. J. Food Microbiol. 2005, 105, 281-295. [CrossRef] [PubMed]

63. Courvalin, P. Vancomycin resistance in Gram-positive cocci. Clin. Infect. Dis. 2006, 42, 25-34. [CrossRef]

64. Arthur, M.; Courvalin, P. Genetics and mechanisms of glycopeptide resistance in enterococci. Antimicrob. Agents Chemother. 1993, 37, 1563-1571. [CrossRef]

65. Clark, N.C.; Cooksey, R.C.; Hill, B.C.; Swenson, J.M.; Tenover, F.C. Characterization of glycopeptide-resistant enterococci from U.S. hospitals. Antimicrob. Agents Chemother. 1993, 37, 2311-2317. [CrossRef]

66. Hashimoto, Y.; Tanimoto, K.; Ozawa, Y.; Murata, T.; Ike, Y. Amino acid substitutions in the VanS sensor of the VanA-type vancomycin-resistant Enterococcus strains result in high-level vancomycin resistance and low-level teicoplanin resistance. FEMS Microbiol. Lett. 2000, 185, 247-254. [CrossRef] [PubMed]

67. Papagiannitsis, C.C.; Malli, E.; Florou, Z.; Medvecky, M.; Sarrou, S.; Hrabak, J.; Petinaki, E. First description in Europe of the emergence of Enterococcus faecium ST117 carrying both vanA and vanB genes, isolated in Greece. J. Glob. Antimic. Resist. 2017, 11, 68-70. [CrossRef] [PubMed]

68. Lee, W.G.; Huh, J.Y.; Cho, S.R.; Lim, Y.A. Reduction in glycopeptide resistance in vancomycin-resistant enterococci as a result of vanA cluster rearrangements. Antimicrob. Agents Chemother. 2004, 48, 1379-1381. [CrossRef] [PubMed] 